\title{
NOTE SUR L'ÉVOLUTION \\ DE L'ÉPAISSEUR DU LARD DORSAL \\ ET DE LA COMPOSITION CORPORELLE \\ UES JEUNES FEMELLES ENTRE 90 ET 169 KILOGRAMMES DE POIDS VIF : INCIDENCE DE LA GESTATION
}

\author{
C. LEGAULT, J. GRUAND et R. GONDOUIN \\ Station de Génétique quantitative et appliquée, \\ Centre national de Recherches zootechniques, I. N. R. A., \\ 78.350 Jouy en Josas \\ Institut technique du Porc, \\ 149, Quai de Bercy, \\ 75579 Paris Cedex 12
}

\section{RÉSUMÉ}

L'étude de l'évolution des caractéristiques de la carcasse en fonction du poids vif a été réalisée sur un échantillon de $86 \mathrm{I}$ femelles de race pure Large White ou issues du croisement Large White $\times$ Landrace abattues entre 90 et $169 \mathrm{~kg}$ de poids vif. Une partie de ces animaux était abattue ıo jours environ après la puberté, alors que l'autre partie était abattue 30 jours environ après insémination au premier ou second ostrus. 337 carcasses (dont 240 de femelles vides et 97 de femelles pleines) ont été découpées. Sur les autres carcasses (dont II 2 de femelles vides et $4^{12}$ de femelles pleines), seules quelques mensurations ont été prises (longueur et épaisseur du lard dorsal).

Le poids à l'abattage étant dépendant du poids à la puberté, nous avons d'abord vérifié que celui-ci était indépendant de l'adiposité de l'animal. Les coefficients de régression linéaire intra-année et type génétique des variables sur le poids vif ont été estimés séparément pour les femelles pleines et les femelles vides. Tous ces coefficients sont positifs à l'exception de celui se rapportant au pourcentage de morceaux nobles. L'épaisseur du lard dorsal augmente linéairement de $0,25 \mathrm{~mm}$ par kilogramme de poids vif : la corrélation entre cette variable et la composition de la carcasse reste pratiquement constante; cette mesure simple est par conséquent un aussi bon estimateur de la qualité des carcasses lourdes que de celles des carcasses d'un poids courant. L'état de gestation affecte significativement l'évolution du rendement et du poids de la poitrine qui augmente plus lentement chez les femelles pleines.

D'une manière générale, l'augmentation du poids vif se traduit toujours par une dégradation de la qualité de la carcasse. En effet, lorsque le poids vif passe de go à I 69 kilogrammes, la longueur augmente de $\mathbf{7} 7 \mathrm{p}$. Ioo les poids des morceaux nobles (Jambon et Longe), du hachage et l'épaisseur du lard dorsal augmentent de 47 à $63 \mathrm{p}$. Ioo; en revanche, le poids de la poitrine augmente de 89 p. Ioo alors que celui des morceaux gras (Bardière et Panne) augmente de 140 p. roo. En pourcentage, le poids des morceaux nobles diminue de 9 p. Ioo et celui des morceaux gras augmente de $3^{6}$ p. Ioo; le rapport Longe/Bardière diminue alors de 35 p. Ioo. 


\title{
SUMMARY \\ CHANGES IN BACKFAT THICKNESS AND BODY COMPOSITION \\ OF YOUNG FEMALE PIGS BETWEEN 90 AND I69 KG LIVE WEIGH'T : INCIDENCE OF GESTATION
}

Changes in carcass traits according to live weight were studied on $86 \mathrm{I}$ purebred Large White females or crossbred Large White-Landrace females slaughtered between 90 and $\mathrm{I} 69 \mathrm{~kg}$ live weight. Part of these animals was slaughtered about ro days after puberty whereas the other part was slaughtered about 3 o days after insemination at the first or second œstrus. 337 carcasses (240 non pregnant and 97 pregnant animals) were cut. As regards the other carcasses (I 2 non pregnant and $4^{\mathrm{I}} 2$ pregnant animals), only tackfat length and thickness were measured.

The weight at slaughter being related to that at puberty, we verified if the latter was independant of the animals' fatness. The intra-year and genotype linear regression coefficients of the variables on live weight were estimated separately for non pregnant and pregnant females. All these coefficients were positive except for that concerning the percentage of valuable primal cuts. Backfat thickness increased linearly by $0.25 \mathrm{~mm}$ per kg live weight; the correlation between this variable and the composition of the carcass remained almost constant. Consequently this simple measurement allows to estimate as well the quality of heavy carcasses as that of carcasses of current weight. Gestation significantly affected the dressing percentage and weight of the belly which increased more slowly in the pregnant animals.

Live weight increase always resulted in a lowering of the carcass quality. When the live weight changed from 90 to $169 \mathrm{~kg}$, the length increased by I $7 \mathrm{p}$. 100 , the weight of valuable primal cuts (ham and loin), of the shoulder and the backfat thickness increased by 47 to $63 \mathrm{p}$. Ioo; conversely, the weight of the belly increased by 89 p. Ioo whereas that of the fat cuts (backfat and flarefat) increased by ${ }_{4} \circ \mathrm{p}$. Ioo. Expressed in percent, the weight of the valuable primal cuts decreased by 9 p. Too and that of the fat cuts increased by $3^{6} \mathrm{p}$. roo; the loin/backfat ratio was reduced by $35 \mathrm{p}$. Ioo.

\section{NOTES DE CONFORMATION \\ ET PERFORMANCES EN STATION \\ DE JEUNES VERRATS DE RACE “ LARGE WHITE »}

\author{
M. MOLÉNAT
}

Station de Génétique quantitative et appliquée,

Centre national de Recherches zootechniques, I. N. R. A., 78350 Jouy en Josas

\section{RÉSUMÉ}

De nombreux verrats utilisés comme reproducteurs sortent des Stations de contrôle individuel. Ils sont d'abord classés sur performances ( 4 critères) puis ensuite jugés sur la conformation extérieure (6 notes de pointage). Pour 49r verrats de race Large White qui ont subi successive- 